




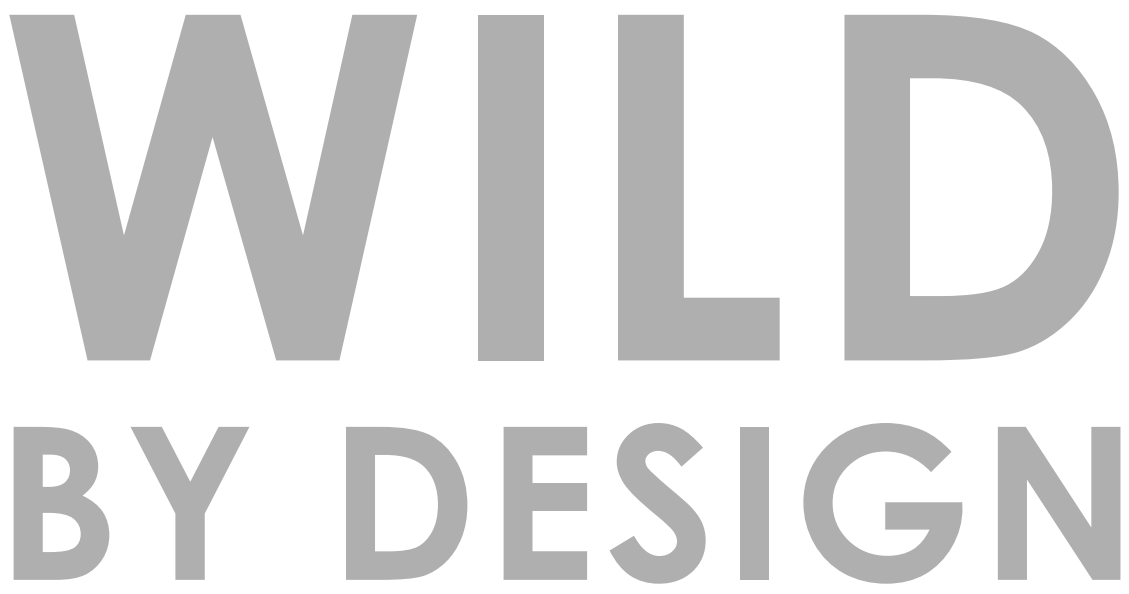

STRATEGIES FOR CREATING LIFE-ENHANCING LANDSCAPES

\section{MARGIE RUDDICK}

OisLandPress Washington | Covelo | London 


\section{Copyright @ 2016 Margie Ruddick}

All rights reserved under International and Pan-American Copyright Conventions. No part of this book may be reproduced in any form or by any means without permission in writing from the publisher: Island Press, 2000 M Street, NW, Suite 650, Washington, DC 20036.

Island Press is a trademark of The Center for Resource Economics.

Library of Congress Control Number: 2015950738

Printed on recycled, acid-free paper

Manufactured in the United States of America

10988765543321

Keywords: Baja, beauty, biodiversity, Chengdu, China, climate change, coastal protection, Coney Island, conservation, ecology, expression, flooding, Governors Island, green infrastructure, habitat, health, India, Kinderhook, landscape architecture, levee, Liberty State Park, living machine, Living Water Park, mental health, Miami Beach, natural infrastructure, New York City, park, particulate matter, Philadelphia, Queens Plaza, recreation, regeneration, reinvention, resilience, restoration, shade, Shillim Retreat and Institute, Staten Island, stewardship, stormwater, sustainable design, Urban Garden Room, urbanization, water quality, Western Ghats 
To parents,

stewards,

teachers,

students,

children-

all children,

and mine. 



\section{CONTENTS}

Preface ..................xi

Introduction ............... . .

Chapter 1: A Laboratory for Wild By Design. . . . . . . 15

Chapter 2: Reinvention . . . . . . . . . . . . . . 45

A diverse array of tactics that can build on the attributes of a place

but change the way it functions and is perceived.

Chapter 3: Restoration . . . . . . . . . . . . . . . . 77

More than just "putting back what was there," restoration engages design strategies for understanding the different functions of restoration.

Chapter 4: Conservation . . . . . . . . . . . . . . . 131

Principles of conservation - to use little, minimize waste, safeguard a landscape that is at risk, make connections, and promote awarenesscan be thoroughly integrated into the design process.

Chapter 5: Regeneration . . . . . . . . . . . . . . 169

Understanding that we are helping to set processes in motion that will sustain a place after the designers are done.

Chapter 6: Expression. . . . . . . . . . . . . . . . . . 187 Refocusing on the art of what we do, the meaning of our work.

Conclusion: What Are We Doing Here, Anyway? . . . . 225 Acknowledgments. . . . . . . . . . . . . . . 233

Illustration and Photograph Credits . . . . . . 237 



\section{Preface}

For a half century, a stretch of Route 1 that runs through Saugus, Massachusetts, just north of Boston, was lit up by the giant glass saguaro cactus in front of Hilltop Steakhouse. The aging highway strip also included the Kowloon Polynesian Restaurant (with an immense tiki god smiling out at the parking lot), and a mini-golf sporting brightly colored dinosaurs. The inventive signs that had sprouted up on the strip over the years seemed to appeal to even the most discerning urbanite; people came from all over to dine on Route 1. But the actual landscape could not have been bleaker: crumbling roadway, acres of empty parking lots, newer big-box retail with all the not-so-hidden loading docks. It may not have been the kind of landscape that would be considered a good fit as the subject of a design studio in landscape architecture at Harvard's Graduate School of Design 10 years ago, when I was a visiting critic. But that is exactly what I proposed.

In all fairness, its didactic potential took me decades to discover. I had been familiar with this commercial strip since I was in college; every time I did the late-night run from my college in Maine back home to New York, or to Boston for a big-city weekend, I loved peering out the Greyhound bus window at this sparkling Vegas of the Northeast. In graduate school as well, the strip played a prominent role in my life: After staying up all night several days in a row for a design review, a particularly brutal hazing ritual that persists to this day, my friends and I would pile into a couple of cars and make the drive from Boston out to Hilltop, to savor 22-ounce steaks served with nuclearscaled baked potatoes and individual side salads made up of half-heads of iceberg topped with Italian dressing.

I loved this particular strip. It was totally out of character for buttondown Boston. It was all light and color and people knocking each other over stampeding for tables. But only a short time before the Harvard Graduate School of Design (GSD) studio, after countless encounters with this land-

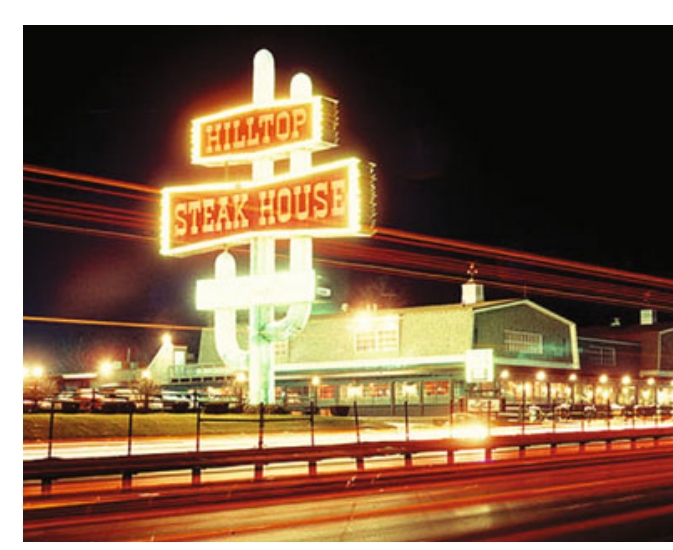

Hilltop Steakhouse, Saugus, Massachusetts. 
scape, I noticed something else. One wintry day, as I was driving at a snail's pace in order not to skid off the road, a toddler in the child's seat behind me, I looked for the first time through the icy parking lots sprouted with these sculptural buildings and signs.

And I noticed something I had never seen before: Behind and slightly downhill from this world of highway and boxes for consuming were wetlands and what looked like a river snaking its way toward the ocean.

I would never before have guessed that if, when we got out of our cars at Kowloon Polynesian Restaurant, we had turned left rather than right, we would have ended up in one of the largest wetland reserves in the Northeast. When I got home I looked for some maps of the area (this was before GoogleEarth) and discovered that it included four major park reserves, several cemeteries, a quarry, and the Saugus River, which runs under Route 1 right in the middle of this amazing strip to meet the ocean less than a mile away.

How extraordinary to have a network of wild reserves surrounding this wild strip of human artifice. This is what made the landscape seem worth studying. Before, it had interested me because it's a place I love, in addition to the fact that struggling smaller-scale highway retail is a landscape type in desperate need of reinvention. But the confluence with an immense natural water ecosystem gave another dimension to the landscape and a new aspect worth studying.

Not everyone saw its potential. When the chair of the landscape architecture department at the GSD called me up the next month to ask whether I had a studio I could teach, I immediately thought of Route 1 and my recent discovery. There was silence on the other end of the phone. At that time, visiting critics usually flew in from out of town to lead really sexy studios that took students to Barcelona, for instance, or Beijing. After clearing his throat, the chair explained to me that most students were interested in serious design studios or, he implied, at least projects that didn't land them on a bleak strip of asphalt less than 10 miles from the school. I didn't hear back.

But a couple of years later, in 2007, a new chair was transforming the GSD's landscape architecture department into a paragon of sustainable design. Urban wetlands and community gardens were in. Blank-slate design was out. Ecological design was, at least in principle, back.

So when the new chair called me up to ask whether I was interested in teaching a studio, I again suggested Route 1 where the Hilltop Steakhouse lights up the night. This time, I got a positive response. 
The GSD chair's support was one thing, but I still needed students. I had to present at the open lottery for all studios, along with an offering in architecture that was going to investigate "the conditionality of the ceiling." Despite my worry that I would attract no students to my little strip project, a handful seemed to get what fascinated me about the place. They threw themselves into the place and the work with abandon. I was thrilled.

The students immersed themselves in the ecology, economics, and cultural background of the area. Their projects looked at how to transform this strip, from rethinking the program, creating more housing and offices, to building wildlife bridges. Two themes ran through every student's scheme: the matrix of wetland and woodland that the students discovered on foot, and fell in love with, and the aesthetic of the strip, or rather developing an aesthetic that would integrate commerce, driving, and nature. These particular students could balance these two themes, the ecological and the design agendas, or rather tolerate and even cultivate a tension between the two. Their schemes were beautiful, arresting. 
The ideas we discussed and wrestled with in that Route 1 studio were the initial inspirations for this book. As I worked on it over the years, I thought about how to give it a title that would describe what we were doing, engaging in both the science of the environment and also the art part. I couldn't come up with anything except this question: "What Are We Doing Here, Anyway?"

The book was something of a response to all the checklists that had proliferated in the new millennium. The Leadership in Energy and Environmental Design (LEED), a guideline for sustainable practices begun in 1998 but really formalized in 2005, had codified "green practices," with checklists that designers followed, gaining points for sustainable practices and winning a platinum or gold or silver LEED certification. Developers had started to market their LEED rating as a sales angle. My experience was that LEED was designed so that designers would do no harm or do less harm. However, the guidelines were so global- "don't build within $x$ number of feet of a wetland," for example-that innovative design that would integrate a new wetland with the built world, bridging the nature-culture divide, was enjoined from some creative and novel solutions. So I started to ask myself, "What are we doing here? Are we saving the planet or are we making something?" The implicit answer was that we were making art and we were engaging in ecological design.

For the next couple of years, I spent time looking at all the projects I had done over the years and tried to come up some sort of system for the process. I started to enumerate the things we were doing, in a prescriptive way, like LEED, but not intended as hard-and-fast rules. The ensuing titles, such as "Cleaning Up Messes," that recur throughout the text are intended only as suggestion, not command. The title for the book remained "What Are We Doing Here, Anyway?"- a little unwieldy, but it kept me asking the questions that kept challenging any formula for "green."

I'd been working intermittently on the manuscript for a few years when, in 2011, I had another perspective-shifting experience in another landscape I was familiar with: my yard. I had been conducting an ad hoc reforestation project over the past 6 years when I received a summons for allowing weeds in my front yard to grow higher than the 10 inches allowed by the Department of Licenses and Inspection for the City of Philadelphia.

The story became viral among my colleagues, and Anne Raver wrote a piece for the New York Times on my home landscape-part reforestation project, part domestic garden-with the title "In Philadelphia a Garden Grows Wild." I received e-mails from around the world, some saying things 
like "Thank God someone understands my approach to gardening." I discovered that I had tapped into a huge movement, the wild gardening movement. I started to understand that what I and my students, and many of my peers, had been doing here was making landscapes that were both wild and clearly designed. Not faux nature but also not slavishly ordered. A little messy but not too much. Intentionally and carefully designed. And, in the best of circumstances, lovingly maintained.

I don't know when the title "Wild by Design" popped into my head, but once it did everyone got it immediately. "That's what I have been trying to do," many of them told me.

I hope this book will give readers an idea of how they might try to bridge the two realms that were traditionally held distant: the hyper-orderly and aestheticized world of designers, and the sometimes mucky but exquisitely beautiful world of ecologists. This book is an encouragement for people to devise their own paths in making change to the environment, not only to follow their preferred or mandated checklists, like LEED, but also to draw from a flexible framework that begins with following their own intuition and their own way of reading the landscape; to tap into the myriad seemingly imperceptible webs and networks that make a place what it is; to follow their passion for landscape, which drove them to their chosen fields or avocations and which, I hope, spurred them to look at this book and think it might be relevant to their work and their lives. 
Her ing

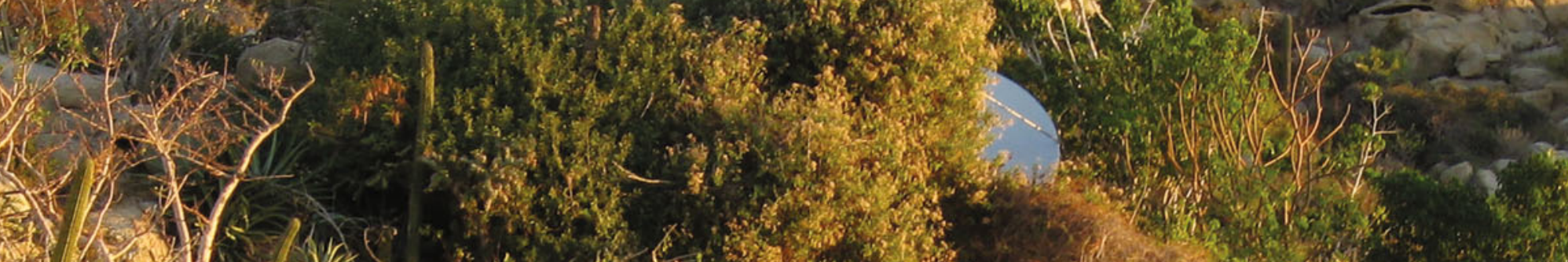

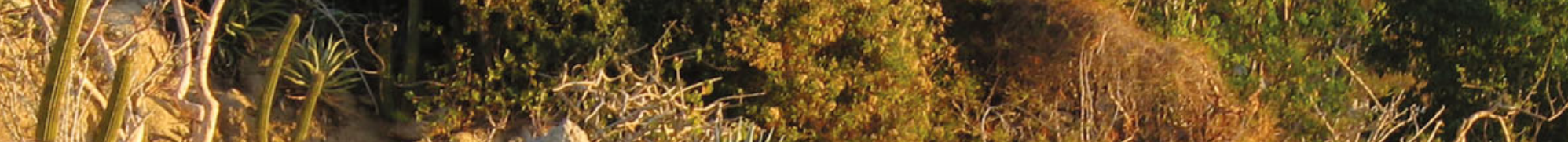

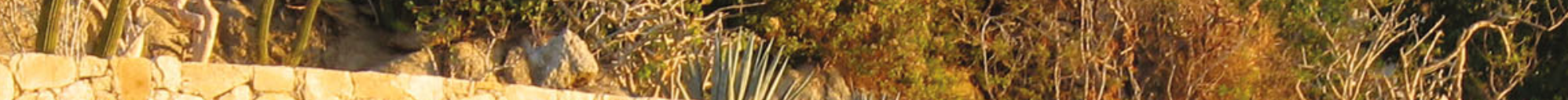
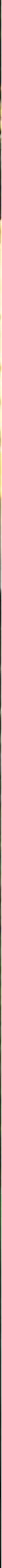

Baja California. 